\title{
The Utilization of Insect-resources in Chinese Rural Area
}

\author{
Chuanhui YI \\ Institute of Applied Ecology and Vocational Education \\ Yunnan Forestry Vocational College \\ Kunming 650224, China
}

Tel: 86-871-501-6956_E-mail: ynkcx2007@163.com

Qiuju HE (Corresponding author)

Faculty of Conservation Biology, Southwest Forestry University

Kunming 650224, China

Tel: 86-871-386-3145Ｅ-mail: ychuanh@public.km.yn.cn

Lin WANG

Institute of Applied Ecology and Vocational Education

Yunnan Forestry Vocational College

Kunming 650224, China

Tel: 86-871-501-6858Ｅ-mail: ynlzywl@126.com

Rongping KUANG

Faculty of Conservation Biology, Southwest Forestry University

Kunming 650224, China

Tel: 86-871-501-6956Ｅ-mail: rongping.kuang@gmail.com

This work is supported by the 948 programs of State Forestry Administration, P.R. China (No.:2005-4-59 and 2008-4-68).

\begin{abstract}
Human beings' uncontrolled exploitation leads to the rapid consumption and depletion of many natural resources. Mankind is facing an unprecedented dilemma in survival and development. Searching, development and utilization of new natural resources will be an important way to solve the current problems. Insects, as an important natural resource needing to be further exploited, have aroused wide concerns and may play an important role in tackling food crisis and natural resources depletion. In China, insects have been being utilized for a long time as an important natural resource and there were lots of practices and experiences in the use of insect, especially in the rural regions. In this paper, we presented the current situation of insect utilization in Chinese rural regions and introduced edible insects being used by ethnic people in Yunnan province of China, the place which is special for its diversity in ethnic culture and folkways. In addition, constraints and prospects in using insect resources were discussed and analyzed as well. It was expected that the experiences in using insect resources in China could be helpful for other countries to promote the utilization of insect resources in near future.
\end{abstract}

Keywords: Insect resource, Utilization, Rural area, China

\section{Introduction}

The shortage of resources has become an important issue involved in human development. Insects have been widely used as food and medicine. As an important natural/biological and sustainable utilized resource, insects should be well developed to assist people dealing with food crisis. In the world, there are about 1.8 million known species, of which one million (55\%) are insect that has one trillion kg of gross weight (GW) (Chen, 2008). 
In China, insect resources are used widespread and people have rich experiences in insect utilization. The history of insect resources utilization is more than 5,000 years in China. As recorded, Chinese people started cultivating artificial Bombyx mori L 5200 years ago (Yan Huang Period), eating insects 3200 years ago and using insects for entertainment over 2000 years ago. The history of insects used as medicine was recorded in "Zhouji" and "Shijing" at early time in China. Pest control started 3000 years ago, later than traditional cultivation culture (6000 years history).There was a record that Chinese people used Oecophylla smaragdina (Fabricius) to control citrus pest in the book "Greenery Record in Southern" (304 AD) (Yang, 1998; Jiang, 1999; Yan, 2001; Li, 2005; Chen, 2008; Chen and Feng, 2009). The aim of this paper is to summarize the current situation and problems of insect-resources utilization in China. Our second aim is to propose a sustainable method of insect-resources usage, which is able to solve food and resources' problems for human beings and providing the theoretical basis to support the sustainable development.

\section{General situation of insect-resources utilization}

\subsection{Insect food}

In China, there is a long history of eating insect (Xing, 1991; Sun et al., 1996; Chen, 1999; Yan, 2001; Peng, et al., 2003; Li, 2005; Wang and Liang, 2006; Chen, 2008). Currently, there are still 26 ethnic groups that are keeping the custom of eating insects in the multi-national area of China, although living standards have been quickly improved (Peng, et al., 2003). For example, people of Guangxi Zhuang minority like eating ants; Yunnan Jinuo minority enjoy eating ants, cockroaches and Omphisa fuscidentalis Hampson; Dai minority use eggs of ants to entertain guests; people in Fujian and Guangdong like eating predaceous diving beetle, the sheath of a egg of Eupolyphaga seu steleophaga(ground beetle), larvae of Scarabeidae, Gryllotalpidae (mole cricket) and Kirkaldyia deyrollei (Vuillefroy); people in Jiangsu, Zhejiang and the three northeastern provinces areas like the edible chrysalis of Bombyx mori L.; people in Chongqing like eating Aspongopus chinensis Dallas; Locusts, Cicadidae and Clanis bilineata tsingtauica Mell are cooked as dishes in Tai'an, Shandong province (Chen and Li, 1996). Eating insects are very common in Hunan province and the edible insects are more than 44 species (Zhu, 2003). Edible insects include 122 species belonging to 48 families of 10 orders in Jiangsu province (Lu, 2005).

At present, there are 177 species of insects belonging to 96 genera of 54 families in 11 orders, such as Hymenoptera, Coleoptera and Lepidoptera, which were commonly used as dishes in China. Besides deep-fry, the cooking methods of insect include burns, roasts and fries. (Chen and Feng, 1999; Yang, 1999; Yan, 2001; Yan, 2001; Wen, 2002; Wang, et al., 2002; Dong and Gao, 2005; Liu, 2005; Liu, et al., 2005; Wang, 2006; Lü, et al., 2006). The most common edible insects in Chinese rural area were listed in Table 1.

With the improvement of people's living standard, insects became more popular due to its delicious taste and high nutrition. Meanwhile, insects have the function of health care and do not produce pollution. Hence, up to date, the traditional insect foods are widespread in China. For instance, Bombyx mori L., the distinctive local insect has disseminated into the large cities around the country in Yunnan; Bee cocoons were only sold in villages and small towns a few years ago. However it has been sold in all parts of China such as Hunan, Guangxi and Yunnan in which there is a complete network of gathering, purchases and sales. The insect food market will definitely be enlarged in the future.

\subsection{Medicinal insect}

In China, the use and effects of medicinal insects were elaborately recorded in many medical references. 22 kinds of insect medicines were recorded in the oldest pharmacology monograph - Shen Nong Ben Zao Jin (Yang, 1998; Jiang, 1999; Yan, 2001; Li, 2005; Chen, 2008; Chen and Feng, 2009; Xiang, 2009). At present, a small number of medicinal insects have been utilized by mass rearing and most of medicinal insects are from field collecting. However, biodiversity and ecological environment has been affected due to uncontrolled collection (e.g. the collection of Chinese caterpillar fungus in some regions). The major medicinal insects applied in China were listed in Table 2.

In Chinese rural area, people still maintain the habit of using medicinal insect now. For instance, in the parts of Yunnan province, Blaps rynchopetera Fairmaire is soaked into alcohols to cure the infantile high fever leading to convulsion and inflammatory swelling of unknown origin. Blaps rynchopetera Fairmaire is also an important ingredient of Yi people's medicine. It is extensively used for anti-bacterium and diminishing inflammation (Lin, et al., 2000; Zhao, et al., 2007). The saliva of Epicauta gorhami Marseul and Mylabris cichorii Linnaeus is used to treat malignant sore of hands and feet and pertinacious tinea. Blatta orientalis is used to cure liver cancer and swine flu in eastern area of Sichuan. Baked ootheca of rearhorse is used for infantile Nocturnal enuresis. Tea with cicada ecdysis has the function of clearing away. In Western Sichuan, people use bee stings to treat rheumatism. 
Medicinal insect is the important component of traditional Chinese medicine, which has the unique curative effect. With the further research, the particular curative effect of insects will be discovered. For example, the role of Meloidae species in anti-cancer and antibacterium function of cantharidin will certainly promote its development and utilization.

\subsection{Insects as industry resource}

Silk has been being used over 7000 years in China and the domestic rearing of Bombyx mori also has a history more than 5000 years. Silk is the traditional export product in China, and Bombyx mori are bred widespread in villages of Zhejiang, Hubei, and Sichuan. However, in these years the substitute of silk product increased and as a result breeding silkworm declined dramatically. Antheraea pernyi Guèrin-Mèneville with the history of 2700-year, took the second place of silk insects produced in China. In the rural area of Liaoning, Henan and Shandong, the cultivation of Antheraea pernyi totaled up to $60 \times 10^{4} \sim 70 \times 10^{4} \mathrm{hm}^{2}$. Moreover, the silk produced by Antheraea pernyi in China occupied $80 \%$ output in the world. Antheraea yamamai Guèrin-Mèneville, Samia cynthia ricina (Donovan), Samia cynthia cynthia (Drurvy) and Eriogyna pyretorum (Westwood),Attacus atlas (L.), were reared in small scale in China now (Yan, 2001; Li, 2005; Chen and Feng, 2009).

Insects that secrete a waxy substance mainly belong to Karria sp. (Lacciferidae), which has more than 20 species in the world. Red lac is the important industrial material, and widely applied in chemical industry, food and medicine. Yunnan province is the most important production bases and $80 \%$ output of red lac in China is from this province (Shi, 1993). The lac insects were introduced into other 9 Southern provinces from Yunnan and the production area is 4 times than before. At moment, red lac's output takes the third place in the world.

Ericerus pela Chavannes is the important wax insects. It have been bred and utilized for over 800 years. Sichuan province is the mainly production base which accounts for $80 \sim 90 \%$ output in China ( $\mathrm{Li}, 2005)$.

\subsection{Pollinating insects}

The normally pollinating insects are the bee species, species of Bombus and species of Megachil. According to the research, pollination of bees can increase the yield of rape from $30 \%$ to $60 \%$ and that of apple from $20 \%$ to $47 \%$. Meanwhile, fertile strawberry increased $38 \%$ and fertile watermelon increased $41.2 \%$ to $95 \%$ due to pollination of bees. Both Bombus and Osmia are well studied. Apis mellifera L., Osmia, Megachile and Bombus have been extended as pollination insects in some rural areas (Xie, et al., 2007; Li and Li, 2004; Guo, et al., 2001). In the rural area, bees are the main pollination insects. Farmers often raise bees in orchards and big greenhouses and they often take bee nests to orchards and oilseed rape fields. However, other pollinating insects are rarely used.

In recent years, the sharp increase of population results in the cultivated land decreased rapidly, leading to the food quality and quantity facing risks. Pollinating insects are able to bring the enormous economic benefits in the production of grain, fruit trees and vegetables, which will certainly improve the exploitation and utilization of pollinated insects around the country. Although there are limited species of pollinating insects being used in agricultural production, the studies on and utilization of insects can be further developed due to the rich insectresources in China.

\subsection{Cultural insects}

The close relationship between Chinese culture and insects, forms the unique Chinese insect culture, which constituted the Chinese nation culture together with other domain culture in rich extent. At present China has more than 100 traditional festivals related to insects, for example, "Silkworm Day" in Nanchong of Sichuan, "Longcan Festival" in Tongxiang County, Zhejiang, "Sheri Festival" of Tujia national minority in west of Hubei Province, Locust and Mantis Festival in Shengning of Guizhou Province, "Insects Delivering Day" in Nantong of Jiangsu Province, "Insect Eating Festival " of Gelao national minority and that of Hani national minority in Xinping of Yunnan, "Double Butterfly Festival" in Jiangsu's Yixing county and so on. The entertainment insect already spreads long time in China as well. The appreciation of insect singing has more than a 2000-year history. Undergoing long-term selection, at present, more than 30 species of entertainment insects are sold in the market, most of which are Gryllidae and Tettigonioidea in order of Orthoptera. In addition, cricket Velarifctorus micado (Saussure) has been very popular as fighting insects in China (Yang, 1998; Jiang, 1999; Yan, 2001; Li, 2005; Chen, 2008).

As a result of the fast development of tourism, potentials of insects in culture are being further exploited in many places of China and the traditional insect culture will obtain the revival. For instant, insect foods, such as bamboo insect, have reappeared at each traveling festival banquet in China's Yunnan Province. 


\subsection{Insects for animal feeding}

The insect used for fowl feeding also has a long history, but the scale is very small. Before the 1990s, in the eastern Sichuan area, duck breeders always collected housefly larva Musca domestica, as the duck feeding. In China, the history is not long in large-scale use of insects for animal feeding. The mass-rearing species are mainly flour weevil Tenebrio molitor L., black powder insect Tenebrio obscurus, barley insect Zophobas morio and the dipteran housefly larva, which are widely used as feeding of chicken, ducks and some other animals. The annual value of flour weevil production exceeded 7 billions RMB, indicating the potential for development of insect feeding (Yang, 1998; Jiang, 1999; Yan, 2001; Li, 2005; Chen, 2008). Along with the people' pursuing of health, nutrition, health care and the ecological food, the species and cultivation scale of feeding insects will further be expanded as well as the market.

\section{Yunnan national minority and edible insect}

Yunnan is located at border region of southwestern China with 25 national minorities, of which 15 minorities are unique. These ethnic groups have a long history in utilization of insect resources and different culture in these groups has formed the unique insect culture in Yunnan Province. The edible insect is the mainly and principal aspect of insect resources in national minority in Yunnan. More than 2000 edible insect species belong to more than 400 families of 14 orders. In Orthoptera, Coleoptera, Hymenoptera and Lepidoptera, edible species reach more than 1200 (Yang, 1999; Chen, 1999).

Wa, Dai, Bulang, Hani, Susu, Jingpo, Deang and Pai people are the unique national minorities that enjoy a long history of insect eating in Yunnan. Wa national minority often eats cocoons which include more than 10 species. Cocoons are often boiled with rice into conjee. In the Dai national minority, foods and snacks were usually made of insects which were an important constitution of Dai national minority food. The common edible insects include the cicada, the bamboo insect, field turtle Belostomatidae, ant Oecophylla smaragdina (Fabricius), ect. Ant Oecophylla smaragdina is also the favorite food in the Hani and Yi national minority. These two minorities always eat the eggs, cocoons, and ant vinegar made up of the formic acid. According to the local villagers' introduction, the edible ant vinegar can keep youthfulness and strengthen the body. The recipe is as following: boil it to die and soak the boiled body for several hours (Chen, 1999; Yang, 1999). The bamboo insect is popular in every national minority of Yunnan. The life cycle of bamboo insect is one generation per year in Dehong of Yunnan. They are induced to diapause by $5^{\text {th }}$ instars in winter. Adults appear at the beginning of July and ends in early September. The bamboo insect is a kind of popular food in Yunnan, especially in Xishuangbanna, Dehong, Honghe and Yuxi and its is a tidbit for guests (Zhao, 1997; Fan, 2001; Mo, et al., 2002; Wen, 2002; Wang, et al., 2002; Qin and Ou, 2004; Zhang, et al. 2006). Every year around National Day, in local markets and restaurants, the price of bamboo insect is 40 60 RMB per kilogram. As a specialty in Yunnan, bamboo insects are being sold in many big cities of China, bring ing considerable economic for the local farmers. 0.3 0.5 kilogram of bamboo insects may be obtained from one bamboo, and can be sold about 12.0-30.0 RMB. Positively promoting the industrial development of bamboo insect is beneficial to the development of local rural economic.

People in many national minorities of Yunnan love eating cicada. The Dai, Jingpo and Deang national minority, often kindle a firebrand in the Ruili dam's rill at summer sunny night for attracting cicada. After wiping off the wing and the foot, people roasted and fried them with vegetable oil. Then a delicacy is done for drinking. The cicada catching in Bulang national minority is very interesting. Normally in the evening, many girls together tread the mountain and catch the cicada on the ground or in the shrubbery, after that, they remove wings, steam and then mash up to be cicada sauce. It is said that the edible cicada sauce has function of clearing away heat and detoxication, alleviating pain and swell. They also fried cocoons of dung beetle Catharsius molossus with chicken eggs.

People of the Hani national minority like cooking locusts. There is a festival of catching the grasshopper. On June 24 (Chinese lunar calendar), everybody will catch grasshopper in the field till 1 kilograms for each family. After that locusts were separated into four parts: one part is heads, one is legs, one is bodies, and the other is wings; then farmers clip them separately and stick in the fields or the drains to threaten uncatched grasshoppers. Half an hour later, all parts of dead grasshoppers will be taken back into bamboo tubes, and brought back to the family as dishes.

Acanthacorydalis orientalis (Mclachlan) is a good food for Bai national minority. In autumn, they will crawl out from rivers and lakes to the riverside and dwell in the cave. This is the best time to capture them. They can be eaten after cleaned and fried. The Cangshan Book on Chinese Medicine said that this insect has the nutritious function, and can be beneficial to human's kidney, waist and energy (Gao, 1994).

Raising bees is a habit in every Yunnan national minority. Every family would like raising bees in Susu Minority. 
Some family raise $4-5$ colonies and some raise more than a dozen of colonies. The method of raising bees is special: people use a hollowed-out log and seal its two ends, keep several eyelets for wild bees' going in and out, place this $\log$ in the forest or under the eaves, let bees to reproduce and make honey, and harvest honey 2-3 times every year.

It is also characteristic that each national minority in Yunnan eat bee cocoon. The bee cocoon is one of the most fastidious foods in the Dulong national minority. It is said that there are many centenarians in the Dulong national minority because of often eating bee cocoon. Gathering and selling bee cocoon is also the major income in countryside. In a village in Lianghe County, every year the bee cocoon helps farmers get incomes of 0.7 million RMB, which becomes one of the three local economic cornerstones (tea, rosin and bee cocoon). The local edible Hymenoptera insect surpasses 12 species, mainly including Vespa velutna auraria Smith, $V$. tropica ducalis Smith, $V$. analis Buysson, $V$. variblis Buysson, $V$. sorror Buysson, $V$. basalis Smith, $V$. ducalis Smith, $V$. mandarinia mandarinia Smith, $V$. bicolor bicolor Fabricius, Provespa barthelemyi (Buysson), Polistes sagittarius Saussure, P. sulcatus Smith needing further identification. The method is strange to seek for honey-combs. People often use fresh pork to entrap the wasp. After the capture, they tie up wasp's leg with a white line attaching a piece of white chicken feather and release the wasp, then follow the flight of wasp to find the honey-comb. At present the local villagers developed capture method. They always collect small honey-comb in spring and then hang it in the completely controlled place (prevents other people gathering) until autumn to collect. However, because of uncontrolled collection and the environmental changes, the local wasp resources decreased year by year. Hence, together with eating habit, developing artificial cultivation of wasp is advantageous in the alleviation of biodiversity destructions and to the promotion of rural economic development.

\section{Constraints and prospects in using of insect-resources}

\subsection{Change traditional concept to promote utilization of insect resources}

The traditional concept is not helpful for the development and utilization of insect resources. People used to think that just a small number of insects such as silkworm and bees that can bring benefits to human being, most of them may bring disadvantages, even disasters (Chen, 2008). In the meanwhile, many people are scared to these small bodies because of their ugly appearance. Consequently, in order to improve the utilization of insect-resources, people's traditional concept to insects should be changed by means of education and propagate. Undeniably insects brought the disaster to people, nevertheless nowadays with the technology development, a great number of diseases caused by insects can be controlled very well. As a group of potential resources, insect resources have presented their potentials in industry, agriculture and ecological environment, and can be an important approach to solve the problem of food and resources shortage. The advantages that insects brought to people are far more than the disadvantages.

\subsection{The technique of large-scale insect cultivation should be further strengthened}

Limited species such as Bombyx mori, Clanis bilineata, the lac insect, the white wax insect, the rice grasshopper, the flour weevil, the housefly, the honeybee, Opisthoplatia orientalis, the Periplaneta Americana, can be produced in large scale. However, most of insect resources (e.g. bamboo insect) were obtained by collection in the field. Every year in the first twenty days of October, people gather the bamboo insect. However the young bamboo was chopped and torn, causing serious damages on host plant. Then only few overwintering populations of bamboo insect can escape gathering and then survive next year. Wasp cocoon, are also completely from artificial collection. In this situation, the output and the quality of insect resources cannot obtain the guarantee and it is difficult to put into industrialization. More important, endless seeking from nature and abusing sharply decrease feral population and biodiversity will be destroyed inevitably. Therefore, in order to better use the insect resource, we should enhance the research on large-scale artificial cultivation of insect resources. The countryside area is the most main place to use insects and we should strengthen the insect resources conservation and do more propaganda work in China.

\subsection{Simple form of food insect and food insect making process}

At present, basically the edible insect product is protozoan or its simple processed products. The processing form is simple (mainly fries), which is not advantageous for the popularization promotion of insect food. Most people not accept insect as foods due to its appearance. This is also the reason that edible insect at present is only popular in distributing areas. In addition, the difficulty in transportation and freshness of insect also limit the popularization of insect food. Therefore, the research on diverse insect-product form and processing form is advantageous to the impetus of insect foods. 
4.4 The development of insect resources is one of important ways solving the shortage of resources

It is generally accepted that insects that have quickly reproductive ability, high adaptability, large individual numbers and huge biomass, which are a giant resource treasure need to be further developed. Along with the rapid increases of population, resources consumption and unusual climatic change, searching and developing new resources has been one of the most important topics at present. The development of insect resources will solve human being's grain and resources issues vigorously. With people' attention on insect resources gradually, people will focus on the insect resource in the near future.

\section{References}

Chen, S. J. \& Li C. H. (1996). Current situation and development strategy of insect food. Food and Nutrition in China, 4, 14-17.

Chen, X. M. (1999). Progress in studies on insect resources. Kunming: Yunnan Science and Technology Press.

Chen, X. M. \& Feng Y. (1999). Edible insects in China. Beijing: China Science and Technology Press.

Chen, X. M. \& Feng Y. (2009). An introduction on insect resources. Beijing : Science Press.

Chen, Z. Y. (2008). Insect world and human society. Guang Zhou: Zhongshan University Press.

Dong, W.G. \& Gao, J. R. (2005). High nutrition insect food-black grasshopper. Food and Drug, 7(6A), 62-63.

Fan, J. G. (2001). Two famous traditional food of Hali people. Science and Technology of Family, 8, 29.

Gao, M. (1994). Insect eating habits of Yunnan ethnic people. Cooking Knowledge, 10, 39-40.

Guo, B. S., Yang J. M. \& Xu, Y. B. (2001). Problems and research advance of the pollination insects. Southwest China Journal of Agricultural Sciences, 14(14), 102-108.

Jiang, S. J. (1999). Medicinal insects in China. Beijing : China Forestry Press.

Li, M. H., Cong, B. \& Li, J. (2004). Mason Bee and Its Application On Fruit Tree Pollination. Journal of Jilin Agricultural University, 26(4), 422-425.

Li, M. L. (2005). Insect Resources. Beijing: China Forestry Press.

Lin, N. Y., Liu, W. Z. \& Li, W. L. (2000). Study on the Chemical Components of Blaps japanensis yunnanenis Mars. Chinese Journal of Ethnomedicine and Ethnopharmacy, 3, 162-164,186.

Liu, Z. H., Li, G. T. \& Wu, F. Z., et al. (2005). Research progress of Clanos bilineata (walker). Journal of Anhui Agricultural Sciences, 36(6), 1101-1102.

Liu, Z. J. (2005). The exploitation of insect food. World Agriculture, 319(11), 45-48.

Lu, Y. B. (2005). Introduction of Study on Edible Insects in Jiangsu. Sichuan Journal of Zoology, 24(1), 49-53.

Lü, F., Liu, Y. S. \& Wang, Z. (2006). Advances in production an d comprehensive utilization of Clanis bilineata tsingtauica. Entomological Journal of East China, 15(3), 192-195.

Mo, X., Zhang, J. \& Gong, J. D. (2002). Research on the biology of bamboo moth. China Science \& Technology Education, 5, 42-46.

Peng, W. Z., Luo, H. R. \& Wang, K. Q. (2003). Present status and development countermeasures on insect food industry. Hunan Agricultural Sciences, 3, 69-71.

Qin, R. H. \& Ou, X. H. (2004). Determination on larval instars of edible bamboo moth. In: Li, M., Wu, Y. J., Wu, C. S. et al. Current Studies on Entomology: Paper Collection for the Conference on $60^{\text {th }}$ Anniversary of Chinese Entomological Society. Beijing : China Agricultural Press, 690-693.

Shi, B. C. (1993). The suitable meteorological demarcation for Kerria yunnanensis associated with its evaluation and utilization. Forest Research, 6(5), 497-503.

Sun, H. C., Shi, H. F. \& Cao, H. (1996). Exploitation and utilization of insect resources-study on edible insects. Chinese Culinary Research, 4, 31-36.

Wang, G. C. \& Liang, H. Y. (2006). The research and usage of insect-based food. Journal of Anhui Agricultural Sciences, 34(2), 317-318.

Wang, Q., Zhou, L. X. \& Yin, J. Z. (2002). Analysis of the nutritional components of Chilo fruscidentalis Hampson. Acta Nutrimenta Sinica, (24)3, 323-324.

Wang, X. C. (2006). The antique and delicious insect food. Cooking Knowledge, 11, 10-11. 
Wang, X. Q., Chen, C. Q. \& Zhao, H., et al. (2002). Rearing Clanis bilineaca in soybean field and its profit. Entomological Knowledge, 39(1), 30-33.

Wen, M. (2002). Some insect food. Yunnan Forestry, 23(6), 24.

Xie, W. W., Jiang, Q. L. \& Diao, Q. Y. (2007). The research progress of bees pollination in China. Apiculture of China, 58(6), 12-14.

Xiang, Y. Y. (2009). Progress on the studies and application of officinal insects in China. Journal of Anhui Agricultural Sciences, 37(7), 3014-3016.

Xing, X. C. (1991). The promising insect food. Territory \& Natural Resources Study, 2, 54.

Yan, M. H. (2001). Clanisbilineata tsingtauica-feed. Journal of Ecology, 18(2), 33.

Yan, S. C. (2001). Resources Entomology. Shengyang: Northeast Forestry University Press.

Yang, D. R. (1999). Edible insect resources and national edible insect culture in Yunnan. Entomological Knowledge, 36(2), 122-125.

Yang, G. H. (1998). Utilization and Industrialization of Insect Resources in China. Beijing: China Agricultural Press.

Zhang, M. L., Xu K. L. \& Xiao R., et al. (2006). Research on Safety edible bamboo moth. Chinese Journal of Food Hygiene, 18(1), 26-28.

Zhao, M., Chen, X. M., \& Sun, L. et al. (2007). Investigation on Distribution and Habitat of Blaps rynchopetera Fairmaire ( Coleoptera: Tenebrionidae) in Yunnan. Forest Research, 20 (3), 356-362.

Zhao, Y. L. (1997). Dai ethnic people eating bamboo worm. Panorama of Chinese Nationalities, 6, 48.

Zhu, X. (2003). Exploitaion and utilization of edible insect resources in Hunnan Province. China Forestry Science \& Technology, 17(2), 12-13. 
Table 1. Common edible insect in China

\begin{tabular}{|c|c|c|c|c|c|c|}
\hline NO & Oder & Species & Areas & Nationality & $\begin{array}{l}\text { Cooking } \\
\text { ways }\end{array}$ & Market \\
\hline 1 & Ephemeroptera & $\begin{array}{l}\text { Ephemerella jianghongensis } \mathrm{Xu} \\
\text { et al }\end{array}$ & $\begin{array}{l}\text { Jingdong county, } \\
\text { Yunnan }\end{array}$ & $\begin{array}{l}\text { Yi,Dai and Harnee et } \\
\text { al. }\end{array}$ & $\begin{array}{l}\text { pan fry or } \\
\text { deep fry }\end{array}$ & seldom sale \\
\hline 2 & Odonata & Crocothemis servilia Drury & $\begin{array}{l}\text { Yunnan Lvchun } \\
\text { county, Honghe } \\
\text { county and Jinping } \\
\text { county }\end{array}$ & $\begin{array}{l}\text { Yao, Miao and } \\
\text { Harnee }\end{array}$ & $\begin{array}{l}\text { Deep fry, } \\
\text { sometime } \\
\text { pan-fry or } \\
\text { boil }\end{array}$ & $\begin{array}{l}\text { frequently } \\
\text { sale }\end{array}$ \\
\hline 3 & Isoptera & $\begin{array}{l}\text { Macrotermes annandalei } \\
\text { Slivestri,M. barneyi (Light), } \\
\text { Odontotermes formosanus } \\
\text { (Shiraki), O. yunnanensis Tsai et } \\
\text { Chen, Coptotermes formosanus } \\
\text { Shiraki }\end{array}$ & $\begin{array}{l}\text { Yunnan, Guizhou, } \\
\text { Sichuan }\end{array}$ & $\begin{array}{l}\text { Han, Yi, Dai, } \\
\text { Harnee,Yao,Miao } \\
\text { minority }\end{array}$ & $\begin{array}{l}\text { Deep-fry or } \\
\text { soak in } \\
\text { alcohol }\end{array}$ & seldom sale \\
\hline 4 & Orthoptera & $\begin{array}{l}\text { Oxya chinensis (Thunberg), } \\
\text { Locusta migratoria manilensis } \\
\text { Meyen, Gryllotalpa unispina } \\
\text { Saussure, Gryllotalpa orientalis } \\
\text { Burmeister, Gryllus bimaculatus } \\
\text { De Geer and Tarbinskiellus } \\
\text { portentosus (Liehtenstern) }\end{array}$ & $\begin{array}{l}\text { all over the } \\
\text { country,especially in } \\
\text { North China }\end{array}$ & $\begin{array}{l}\text { Mainly Han, } \\
\text { sometime other } \\
\text { minority }\end{array}$ & $\begin{array}{l}\text { Deep-fry, } \\
\text { sometimes } \\
\text { toast }\end{array}$ & $\begin{array}{l}\text { frequently } \\
\text { sale }\end{array}$ \\
\hline 5 & Homoptera & $\begin{array}{l}\text { Cryptotympana atrata Fabricius, } \\
\text { Lawana imitate Melichar, } \\
\text { Darthula hardwicki (Gray)and } \\
\text { Ericerus pela Chavanness }\end{array}$ & all over the country & all nationality & $\begin{array}{l}\text { Deep-fry, } \\
\text { sometimes } \\
\text { boil, toast, } \\
\text { pan-fry }\end{array}$ & $\begin{array}{l}\text { frequently } \\
\text { sale }\end{array}$ \\
\hline 6 & Hemiptera & $\begin{array}{l}\text { Tessaratoma papillosa Drury, } \\
\text { Eurostus validus Dallas, } \\
\text { Lethocerus indicus Lepeletier et } \\
\text { Servilleand Aspongopus chinensis } \\
\text { Dallas }\end{array}$ & Southwest of China & $\begin{array}{l}\text { Han and minority of } \\
\text { Southwest of China }\end{array}$ & baking & Seldom sale \\
\hline 7 & Coleoptera & $\begin{array}{l}\text { Oryctes rhinoceros (L.), } \\
\text { Stromatium longicorne } \\
\text { (Newman), Aromia bungii } \\
\text { Faldermann,Anoplophora nobilis } \\
\text { Gangbauer, Batocera horsfields } \\
\text { Hope), Cybister japonicus Sharp, } \\
\text { C. tripunctatus } \text { Olivier, } \\
\text { Cyrtotrachelus bugueti Guer, } \\
\text { Cyrtotrachelus longimanus } \\
\text { Fabricius, C. buqueti } \\
\text { Guerin-Meneville and } \\
\text { Otidognathus davidis Fabr. }\end{array}$ & Southwest of China & $\begin{array}{l}\text { minority in } \\
\text { Southwest China }\end{array}$ & $\begin{array}{l}\text { pan-fry or } \\
\text { deep-fry }\end{array}$ & frequently \\
\hline 8 & Megaloptera & $\begin{array}{l}\text { Acanthacorydalis orientalis } \\
\text { (Mclachlan) }\end{array}$ & $\begin{array}{l}\text { Sichuan and West of } \\
\text { Yunnan }\end{array}$ & Tibetan, Bai et al. & deep-fry & $\begin{array}{l}\text { sometime } \\
\text { sale }\end{array}$ \\
\hline 9 & Lepidoptera & $\begin{array}{l}\text { worm grass, worm tea, bamboo } \\
\text { weevil, Omphisa fuscidentalis } \\
\text { Hampson,oak } \\
\text { silkworm,Antheraea pernyi } \\
\text { Guèrin-Mèneville, silkworm, } \\
\text { hawk moth Clanis bilineata } \\
\text { tsingtauica Mell }\end{array}$ & all over the country & All nationality & deep-fry & $\begin{array}{l}\text { frequently } \\
\text { sale }\end{array}$ \\
\hline 10 & Diptera & Musca domestica L. & Sounthern China & Han nationality & deep-fry & seldom sale \\
\hline 11 & Hymenoptera & $\begin{array}{l}\text { Apis dorsata (Fabricius), Apis } \\
\text { florae Fabricus, Vespa sp. }\end{array}$ & all over the country & all nationality & deep-fry & $\begin{array}{l}\text { frequently } \\
\text { sale }\end{array}$ \\
\hline
\end{tabular}


Table 2. Main medicinal insect application in China

\begin{tabular}{|c|c|c|c|c|c|}
\hline Source & Species & Available part & Efficacy & Utilization & $\begin{array}{l}\text { Areas of cultivation } \\
\text { or collection }\end{array}$ \\
\hline \multirow[t]{6}{*}{$\begin{array}{l}\text { Large-scale } \\
\text { artificial } \\
\text { breeding } \\
\text { species }\end{array}$} & $\begin{array}{l}\text { Eupolyphaga sinensis } \\
\text { Walker and } \\
\text { Opisthoplatia } \\
\text { orientalis Burmeister }\end{array}$ & $\begin{array}{l}\text { The whole } \\
\text { body }\end{array}$ & $\begin{array}{l}\text { Promoting blood circulation and } \\
\text { removing blood stasis, subsiding a } \\
\text { swelling }\end{array}$ & $\begin{array}{l}\text { Curing traumatic injury, } \\
\text { irregular menses }\end{array}$ & The whole of China \\
\hline & $\begin{array}{l}\text { Periplaneta } \\
\text { Americana (L.) }\end{array}$ & $\begin{array}{l}\text { The whole } \\
\text { body }\end{array}$ & $\begin{array}{l}\text { Promoting blood circulation and } \\
\text { removing blood stasis }\end{array}$ & $\begin{array}{l}\text { Curing enterogastric disease, } \\
\text { trauma }\end{array}$ & Yunnan \\
\hline & $\begin{array}{l}\text { Blatta orientalis } \mathrm{L} . \\
\text { and Periplaneta } \\
\text { australasiea } \\
\text { (Fabricius) }\end{array}$ & $\begin{array}{l}\text { The whole } \\
\text { body }\end{array}$ & $\begin{array}{l}\text { Promoting blood circulation and } \\
\text { removing blood stasis, subsiding a } \\
\text { swelling }\end{array}$ & $\begin{array}{l}\text { Curing sore throat, ascites due } \\
\text { to cirrhosis, trauma by snake } \\
\text { and insect, pyogenic } \\
\text { infections }\end{array}$ & Parts of Yunnan \\
\hline & $\begin{array}{l}\text { Melaphis chinensis } \\
\text { (Bell) }\end{array}$ & $\begin{array}{l}\text { Chinese } \\
\text { gallnut }\end{array}$ & $\begin{array}{l}\text { Astringent, hemostasis, } \\
\text { hustenmildernd, antidiarrheal }\end{array}$ & $\begin{array}{l}\text { Curing coughing and bleeding } \\
\text { wound }\end{array}$ & $\begin{array}{l}\text { Guizhou,Shanxi,andS } \\
\text { ichuan }\end{array}$ \\
\hline & $\begin{array}{l}\text { Polyrhachis vicina } \\
\text { Roger }\end{array}$ & $\begin{array}{l}\text { The whole } \\
\text { body }\end{array}$ & $\begin{array}{l}\text { Hepatorenal health care, subsiding } \\
\text { a swelling and detoxifcation }\end{array}$ & Curing hepatitis B & Yunnan \\
\hline & $\begin{array}{l}\text { Hydrillodes morose } \\
\text { Butler and Aglosssa } \\
\text { dimidiate Haworth }\end{array}$ & Dejection & $\begin{array}{l}\text { Quenching one's thirst, subsiding a } \\
\text { swelling and detoxifcation }\end{array}$ & $\begin{array}{l}\text { Curing diarrhea, nosebleed, } \\
\text { wound, unnamed swelling }\end{array}$ & $\begin{array}{l}\text { Chengbu county and } \\
\text { Tongdao county in } \\
\text { Hunan province, } \\
\text { Sanjiang county in } \\
\text { Guanxi province }\end{array}$ \\
\hline \multirow[t]{6}{*}{$\begin{array}{l}\text { Species } \\
\text { collected in } \\
\text { the field }\end{array}$} & Mantodea & $\begin{array}{l}\text { The whole } \\
\text { body, egg } \\
\text { sheath }\end{array}$ & $\begin{array}{l}\text { The whole body is helpful for } \\
\text { bodily health, reproductive } \\
\text { system, relieving clonus; Egg } \\
\text { sheath tonifying kidney-yin and } \\
\text { reduce urination }\end{array}$ & $\begin{array}{l}\text { The whole body cure asthenia, } \\
\text { impotence and seminal } \\
\text { emission, febrile convulsion, } \\
\text { enuresis, hemorrhoids, } \\
\text { panasthenia. } \\
\text { Egg sheath cure enuresis, } \\
\text { spermatorrhea, frequency of } \\
\text { urinatior, lumbago due to } \\
\text { deficiency of the kidney, } \\
\text { panasthenia, irregular } \\
\text { leucorrh(o)ea, morbid } \\
\text { menses. }\end{array}$ & The whole of China \\
\hline & Meloidae & $\begin{array}{l}\text { The whole } \\
\text { body }\end{array}$ & $\begin{array}{l}\text { Removing blood stasis, relieving } \\
\text { convulsion }\end{array}$ & Curing skin ulcer, cancer & Southern China \\
\hline & Myrmeleontidae & Larvae & $\begin{array}{l}\text { Relieve fever, Removing blood } \\
\text { stasis, relaxing the bowels }\end{array}$ & $\begin{array}{l}\text { Curing fever, belly-bound, } \\
\text { despepsia of kid, trauma, } \\
\text { tympanitis. }\end{array}$ & The whole of China \\
\hline & Hepialidae & Cordyceps & $\begin{array}{l}\text { Protecting lung, tonifying } \\
\text { kidney-yin and stop bleeding, } \\
\text { preventing phlegm from forming } \\
\text { and stopping coughing }\end{array}$ & 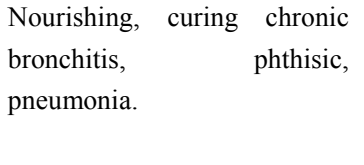 & $\begin{array}{ll}\text { Yunnan, } & \text { Sichuan, } \\
\text { Tibet, } & \text { Qinghai, } \\
\text { Guizhou } & \end{array}$ \\
\hline & Vespa and Polistes & $\begin{array}{l}\text { Bee venom, } \\
\text { honeycomb }\end{array}$ & $\begin{array}{l}\text { Bee venom is capable of } \\
\text { antibiosis, subsiding a swelling } \\
\text { and relieving pain, Hypolipidemic, } \\
\text { invigorating the circulation of } \\
\text { blood; Honeycomb is capable of } \\
\text { antibiosis, relieving pain, } \\
\text { diminishing inflammation, } \\
\text { anticancer }\end{array}$ & $\begin{array}{l}\text { Bee venom cure rheumatoid } \\
\text { arthritis, trauma; Honeycomb } \\
\text { cure swelling, cancer. }\end{array}$ & The whole of China \\
\hline & $\begin{array}{l}\text { Aspongopus } \\
\text { chinensis Dallas }\end{array}$ & $\begin{array}{l}\text { The } \\
\text { body }\end{array}$ & $\begin{array}{l}\text { Tonifying kidney-yin, dispersing } \\
\text { stagnated hepatoqi to stop pain }\end{array}$ & $\begin{array}{l}\text { Curing Deficiency of both } \\
\text { Spleen and Kidney, } \\
\text { impotence, and gastric cancer }\end{array}$ & Southern China \\
\hline
\end{tabular}

